\title{
Editorial
}

\section{Palavras do Prof. Adib D. Jatene}

Desde maio de 1951 - quando ainda acadêmico iniciava meu treinamento em cirurgia na equipe do Prof. Zerbini -, acompanho a evolução da cardiologia e da cirurgia cardiaca.

Participei do que chamo "fase heróica", quando, para medir pressões do ventrículo esquerdo, fazíamos, com agulha da raquianestesia, punção da ponta do coração detectada pela palpação e orientávamos a direção da agulha inferindo a posição do orifício aórtico. Comparado aos cateteres, aterótomos, stents, aquilo soa hoje como uma aventura.

$\mathrm{Na}$ cirurgia, passamos, das operações para tratar coartação da aorta, canal arterial e realização de derivações aortopulmonares para a cirurgia intracardiaca cega, à parada cardiaca com hipotermia, chegando à circulação* extracorpórea, às próteses valvulares, à correção das cardiopatias mais complexas e, até mesmo, à epopéia dos transplantes de coração.

Durante toda esta evolução, foi sendo organizada a especialidade. Inicialmente como Departamento da Sociedade Brasileira de Cardiologia e, quando atingimos cerca de 200 cirurgiōes em todo o País, foi criada a Socièdade Brasileira de Cirurgia Cardiovascular, com equipes atuando em todas as regiões do Brasil.

O único veículo de que dispúnhamos para a divulgação impressa desta caminhada era a revista "Arquivos Brasileiros de Cardiologia", que se mostrava incapaz de absorver toda a produção cientifica dos cirurgiões. Foi amadurecendo a idéia de se criar uma Revista da Sociedade, o que vinha sendo pleiteado em nossas Assembléias.

Afinal, decidida a criação da Revista, fui eleito Editor, esperando ficar pouco tempo neste cargo até que se consolidasse a publicação. Passaram-se dez anos, e chegou o momento de me retirar.
De edição quadrimestral passamos a trimestral, e estamos com todos os fascículos publicados, sempre com o padrão gráfico preservado e os trabalhos exprimindo a alta qualificação dos associados da SBCCV.

Desde o início, contei com a competência e dedicação da bibliotecária Lylian de Vasconcellos, que acompanha a Sociedade desde a fundação do Departamento, em 1969. Foi ela quem cuidou da editoração, da organização biblioteconômica, dos anúncios, do acompanhamento dos trabalhos gráficos, das revisões, da administração, enfim, foi o que se pode chamar de guardiā, para que não houvesse solução de continuidade das publicações. Suportou atrasos ocasionais, problemas financeiros, mas a tudo superou com o entusiasmo que a caracteriza.

Outro nome que merece a minha maior gratidão é o do Prof. Geraldo Verginelli. Após sua aposentadoria, e mesmo antes, assumira a tarefa de revisão da parte técnica e formal dos artigos. Como Professor, querido de todos, orientou e discutiu cada texto, garantindo a excelência dos artigos.

O Conselho Editorial colaborou muito e, por não poder citar todos, faço referência a três nomes, que, na fase mais recente, se empenharam na recuperação dos números em atraso, permitindo que eu deixasse $o$ cargo com a Revista seguramente atualizada. Refiro-me aos Drs. Fábio Biscegli Jatene, Luís Alberto Dallan e Pablo Pomerantzeff, que, juntamente com o Verginelli e a Lylian, trabaIharam para chegar ao volume 11 absolutamente em dia.

De nossos anunciantes, todos indispensáveis, devo destacar o patrocínio que, nesta última fase, nos deu a Biossintética, fundamental para a atualização obtida. 
Deixo a Revista e passo o cargo de Editor ao Dr. Fábio Biscegli Jatene, eleito na última Assembléia da SBCCV. Pelo que fez nestes anos em que colaborou, estou indubitavelmente seguro de que novos passos serão dados.

Já está garantida a circulação da Revista em todos os países da América do Sul e México. Acredito que, pela normalidade de sua publicação, logrará indexação no Index Medicus e integrará a Internet.

É confortador, a quem há 45 anos testemunha o desenvolvimento do setor, ver, em praticamente todos os Estados, a especialidade praticada por profissionais competentes, qualificados pela SBCCV e exercendo com respeito aos princípios éticos deixados por nosso patrono maior, que é o sempre presente e querido Prof. Zerbini.

Deixo a Revista com a sensação do dever cumprido e com a certeza da continuidade de aprimoramentos que acompanharão o progresso da especialidade no Brasil.

O importante não é criar-uma revista, mas sim mantê-la e aperfeiçoá-la para que seja, de fato, a caixa de ressonância de todo o esforço dos membros da SBCCV e para que, registrando seus êxitos e suas contribuições, coloque bem alto o renome e o prestígio dos cirurgiōes brasileiros. 